\title{
Predicting Hourly Stream Temperatures Using the Equilibrium Temperature Model
}

\author{
Cindie Hébert1, Daniel Caissie ${ }^{2 *}$, Mysore G. Satish ${ }^{1}$, Nassir El-Jabi ${ }^{3}$ \\ ${ }^{1}$ Faculty of Engineering, Dalhousie University, Halifax, Canada \\ ${ }^{2}$ Fisheries and Oceans, Moncton, Canada \\ ${ }^{3}$ Faculty of Engineering, Université de Moncton, Moncton, Canada \\ Email: cindie.hebert@umoncton.ca, ㄹaniel.caissie@dfo-mpo.gc.ca, mysore.satish@dal.ca, \\ nassir.el-jabi@umoncton.ca
}

Received 24 February 2015; accepted 12 March 2015; published 13 March 2015

Copyright (C) 2015 by authors and Scientific Research Publishing Inc.

This work is licensed under the Creative Commons Attribution International License (CC BY). http://creativecommons.org/licenses/by/4.0/

(c) (i) Open Access

\begin{abstract}
Water temperature is a key physical habitat determinant in lotic ecosystems as it influences many physical, chemical and biological properties of rivers. Hence, a good understanding of the thermal regime of rivers is essential for effective management of water and fisheries resources. This study deals with the modeling of hourly stream water temperature using the equilibrium temperature model. This water temperature model was applied on two thermally different watercourses, namely, the Little Southwest Miramichi River (LSWM) and Catamaran Brook (CatBk; New Brunswick). The equilibrium temperature model is a simplified version of a deterministic model. As such, in the equilibrium temperature model the total heat flux at the surface is assumed proportional to the difference between the water temperature and an equilibrium temperature. In the present study, the equilibrium temperature was assumed to vary linearly with hourly air temperature. This study showed that there was a good relationship between the equilibrium and air temperature at the hourly time scale. The root-mean-square error (RMSE) obtained with the hourly equilibrium temperature model was similar to results reported in previous studies with values of $1.05^{\circ} \mathrm{C}$ (CatBk) and $1.36^{\circ} \mathrm{C}(\mathrm{LSWM})$. The model's performance was best in late summer and autumn when water levels were low. In contrast, the presence of snowmelt in the spring resulted in poorer performances. This study also showed good results in estimating the daily mean $\left(T_{m e a n}\right)$ and maximum $\left(T_{\max }\right)$ water temperatures from the predicted hourly water temperatures, which were often required in fishery management.
\end{abstract}

\section{Keywords}

Stream Temperature, Modeling, Equilibrium Temperature

\footnotetext{
${ }^{*}$ Corresponding author.
}

How to cite this paper: Hébert, C., Caissie, D., Satish, M.G. and El-Jabi, N. (2015) Predicting Hourly Stream Temperatures Using the Equilibrium Temperature Model. Journal of Water Resource and Protection, 7, 322-338. 


\section{Introduction}

Water temperature has both economic and ecological significance when considering issues such as water quality and biotic conditions in rivers [1]. For example, fish habitat suitability is highly dependent on stream water temperatures. The thermal regime of rivers is influenced by many factors such as atmospheric conditions, topography, riparian vegetation, stream discharge and streambed thermal fluxes [1] [2]. It is therefore important to use adequate water temperature models to effectively predict water temperature variability. Hourly water temperatures provide a better understanding of diel variability, including maximum and minimum water temperatures, which are very important for aquatic habitat and fisheries management [3].

Stream water temperatures have been studied for many years (e.g., [4] [5]) and studies have shown that water temperature controls the rate of decomposition of organic matter, dissolved oxygen content and chemical reactions in general. Stream water temperature can also affect recreational activities such as swimming and fishing. Some studies have mainly focused on the impact of forest harvesting on water temperature while others have focused on fish habitat related issues. For example, studies have found that stream water temperature dynamics can influence many fish habitat conditions including the growth rate of fishes, aquatic invertebrates and others [6] [7]. Stream temperature has also been monitored in order to evaluate the impact of human activities due to urbanization [8], thermal pollution [9], etc. Understanding the thermal regime of rivers in forested ecosystems has played an important role in the development of water temperature models, as valuable information has been learned from heat exchange processes [10]. However, increased interest in river temperature has also been noted recently due the potential effects of climate change [11] [12].

Water temperatures models can be classified into two groups: deterministic and statistical models [1]. The statistical approach predicts water temperatures by relating water temperatures to relevant meteorological parameters (usually air temperature). Deterministic models consider the cause and effect relations between meteorological parameters and stream temperature [4] [13]. Deterministic models can be complex if all heat fluxes are considered. This modeling approach requires many meteorological and hydrological data that are not always easily monitored, accessible or available. The equilibrium temperature model can be an alternative to statistical and deterministic models. This approach was first developed to simplify the expression of the total heat flux [14]. As such, the total heat flux at the surface is assumed proportional to the difference between the water temperature and an equilibrium temperature $T_{e}[15]$. Many studies have used the concept of the equilibrium temperature to estimate stream temperatures [15]-[19].

Caissie et al. [15] developed an equilibrium temperature model for the prediction of daily stream water temperatures in selected rivers within the Miramichi River catchment (New Brunswick, Canada). They expressed the total heat flux as a function of water temperature and the equilibrium temperature. A linear relationship between the equilibrium temperature and daily mean air temperature was assumed. This approach will also be used in the present study, but at hourly time scale. In fact, few studies have predicted hourly stream temperatures using stochastic and equilibrium temperature models, as most have focused on daily mean water temperatures [19] [20]. Hourly water temperatures are very important for fishery management as they provide information on daily minimum and maximum water temperatures. These daily extremes are sometimes useful to assess the stress and recovery periods of aquatic resources, particularly salmonids, during high temperature events [3].

Therefore, the goal of the present study was to adapt the equilibrium temperature concept to estimate hourly stream temperature and apply this model to two thermally different watercourses within the Miramichi River. The specific objectives were 1) to apply an equilibrium temperature model at the hourly time scale, 2) to apply the model on two thermally different watercourses, 3 ) to perform a seasonal analysis (i.e. spring, summer and autumn) to compare the performance of the model under different meteorological and hydrological conditions, and 4) to calculate the daily mean and maximum water temperatures from the predicted hourly water temperatures.

\section{Methodology}

\subsection{Equilibrium Temperature Model}

Deterministic models consider relevant energy components of the total heat flux at the water surface interface (net shortwave radiation, net long wave radiation, convection, evaporation) as well as the streambed heat flux to predict stream water temperatures [20]-[23]. In the application of the equilibrium temperature model of the present 
study, we assumed that the streambed heat flux was secondary to surface heat fluxes, and therefore the streambed heat flux was neglected to keep the model simple.

In the equilibrium temperature model, the exchange of heat flux between the atmosphere and the river is assumed to be proportional to the difference between the water temperature and an equilibrium temperature $T_{e}$. The development of this model is provided in previous studies (e.g., [14] [15]). The equilibrium temperature represents the water temperature at which the total heat flux at the surface of the river is zero.

Studies have shown that good relationships exist between air and equilibrium temperatures [16] and therefore, $T_{e}$ can be expressed as a linear function of air temperature [15] [19]. The equation of thermal energy, for wellmixed rivers and assuming no longitudinal variation of water temperature, is expressed as follows [15] [19]:

$$
\frac{d T_{w}}{d t}=\frac{H_{t}}{c \rho y}=\frac{K\left(T_{e}-T_{w}\right)}{c \rho y}=\frac{K}{c \rho y}\left(\left(\alpha T_{a}+\beta\right)-T_{w}\right)
$$

where $T_{w}$ represents the water temperature $\left({ }^{\circ} \mathrm{C}\right), t$ is the time (hour), $H_{t}$ is the total heat flux per area at the surface-water interface $\left(\mathrm{W} \mathrm{m}^{-2}\right), c$ is the specific heat of water $\left(4.19 \times 10^{-3} \mathrm{MJ} \mathrm{kg}^{-1 \circ} \mathrm{C}^{-1}\right), \rho$ is the water density $\left(1000 \mathrm{~kg} \mathrm{~m}^{-3}\right), y$ is the mean water depth (m), $K$ represents the thermal exchange coefficient $\left(\mathrm{W} \mathrm{m}^{-2 \circ} \mathrm{C}^{-1}\right), T_{e}$ is the equilibrium temperature $\left({ }^{\circ} \mathrm{C}\right), \alpha$ and $\beta$ are the linear regression coefficients relating air to the equilibrium temperature, and $T_{a}$ is the air temperature $\left({ }^{\circ} \mathrm{C}\right)$.

\subsection{Water Temperature Model}

The equilibrium temperature model in the present study will be applied at an hourly time scale during open water conditions, i.e. from 15 April to 31 October for years 1998 to 2007. The open water period was selected based on historical data showing no ice cover. The study was divided into two periods: calibration (1998-2002) and validation (2003-2007). During the calibration period, water temperatures $\left(T_{w}\right)$, air temperatures $\left(T_{a}\right)$, and water level $(y)$ were used to calibrate the model, i.e. calculation of coefficients $\alpha$ and $\beta$ as well as the thermal exchange coefficient $(K)$. The calibration was done by minimizing the sum of square differences between observed and predicted water temperatures. In order to keep the model simple, the coefficients of linear regression $(\alpha$ and $\beta$ ) and the thermal exchange coefficient $(K)$ were considered constant for each river and for all years, as in previous studies [15] [19]. The validation period (years 2003-2007) was then used to test the model, using the parameters $(\alpha, \beta$, and $K)$ previously calculated during the calibration period. The prediction of water temperatures in this study used the equilibrium temperature model in a two-step process. The first step consisted in predicting the daily water temperatures from equilibrium temperature model using daily air temperatures. Then the second step consisted in predicting hourly water temperatures using hourly air temperatures. During the calibration, observed daily water temperatures were used to predict hourly water temperatures; however during the validation, the simulated daily mean water temperatures were used in the modeling.

A seasonal analysis was also performed to examine the performance of the model under different hydrometorological conditions. Three seasons were selected (spring, summer and autumn). Spring was between 15 April and 20 June (days 105 - 171), summer between 21 June and 2September (days 172 - 263) and autumn between 22 September and 31 October (days 264 - 305).

\subsection{Study Area}

The equilibrium temperature model was applied on two watercourses (Catamaran Brook and Little Southwest Miramichi River) of different sizes within a same hydrometeorological region. The two study sites are located on the river Miramichi system (New Brunswick, Canada), which is world renowned for its population of Atlantic salmon (Figure 1). This river receives an annual precipitation ranging from $860 \mathrm{~mm}$ to $1365 \mathrm{~mm}$, with a long-term average of $1142 \mathrm{~mm}$ [24]. Mean monthly air temperature varies between $-11.8^{\circ} \mathrm{C}$ (January) and $18.8^{\circ} \mathrm{C}$ (July). The mean annual runoff was estimated at $714 \mathrm{~mm}$, ranging from $631 \mathrm{~mm}$ to $763 \mathrm{~mm}$. The vegetation consisted mainly of second-growth, mature forest species estimated at $65 \%$ coniferous and $35 \%$ deciduous [25].

The first study site is located on the Little Southwest Miramichi River (LSWM) at approximately $25 \mathrm{~km}$ from the river mouth, and just above the confluence of Catamaran Brook (Figure 1). The drainage area of this basin is 


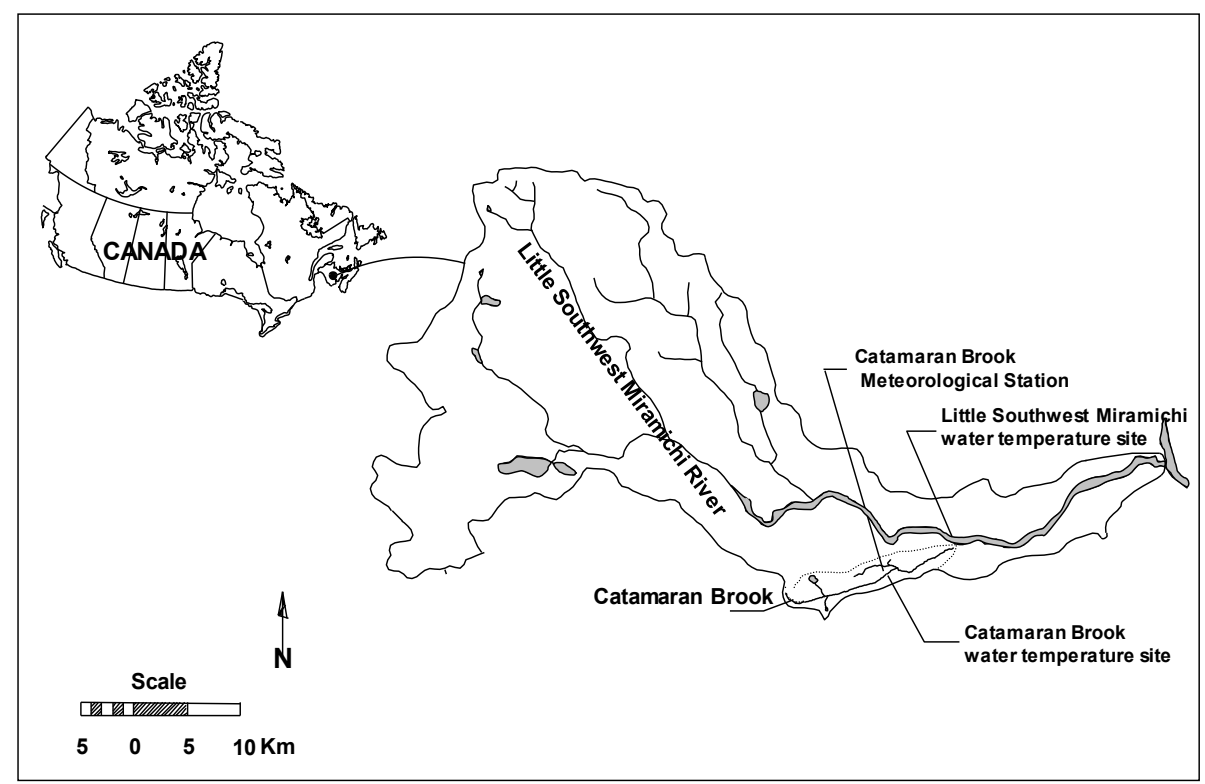

Figure 1. Map showing the location of the water temperature sites (Catamaran Brook and Little Southwest Miramichi River) and the location of the meteorological station.

$1190 \mathrm{~km}^{2}$. The LSWM has a river width of approximately $80 \mathrm{~m}$, with a depth of $0.52 \mathrm{~m}$ on average during mean flow conditions. No lateral variation of water temperatures was observed due to the well-mixed nature of the river [20]. The forest along the LSWM is mainly composed of $70 \%$ hardwood, with presence of $30 \%$ softwood. The canopy closure was less than $20 \%$. The second study site is located on Catamaran Brook (CatBk) approximately $8 \mathrm{~km}$ upstream of the mouth (Figure 1). This site is part of a 15 -year multidisciplinary hydrobiological research study aimed at quantifying stream ecosystem processes and the impact of timber harvesting [25]. Catamaran Brook has a drainage area of $27 \mathrm{~km}^{2}$ at the study site, an average stream width of $9 \mathrm{~m}$ and a depth of $0.16 \mathrm{~m}$. Catamaran Brook is well-mixed due to high turbulence, similar to LSWM, but the brook is more sheltered by streamside vegetation and upland slopes. The canopy closure for Catamaran was estimated at $55 \%-65 \%$ with a forest composition of $60 \%$ hardwood and $40 \%$ softwood. Site characteristics for both studied watercourses are presented in Table 1.

\subsection{Data Collection}

Water temperature and meteorological data for the equilibrium temperature models were collected for the period of 15 April (day 105) to October 31 (day 304) and for years 1998 to 2007 at both CatBk and LSWM. This period corresponded to the period of the year without ice cover, i.e. open water condition. Some years had missing data for a few days and these days were not included in the modeling. Data were separated into two samples: calibration data (1998-2002) and validation data (2003-2007). Meteorological data, for both study watercourses, were collected hourly at the meteorological station located at mid-basin on the CatBk (Figure 1). The meteorological station represents a land-based meteorological station, but was less than $1 \mathrm{~km}$ from the CatBk water temperature site and less than $8 \mathrm{~km}$ from the LSWM site. Meteorological conditions from the Catamaran Brook meteorological station were representative of those experienced within the two watercourses.

At the Catamaran Brook meteorological station, air temperature and relative humidity were measured $2 \mathrm{~m}$ above the ground using a Vaisala Relative Humidity and Temperature sensor. A RM young wind monitoring sensor monitored wind speed and direction at a height of $10 \mathrm{~m}$. Incoming solar radiation was measured using a Kipp and Zonen Silicon Pyranometer. Water temperature was measured with a 107B Water Temperature Probe (Campbell Scientific Corps.) for both CatBk and LSWM. All sensors were scanned every 5 seconds by a CR10 datalogger and hourly averages were then calculated. Daily discharge was obtained from Environment Canada's hydrometric station (01BP001 for LSWM and 01BP002 for CatBk) on both river systems. The mean daily water depth was obtained from discharge and a power function as described in Caissie et al. [20]. 
Table 1. Study site characteristics for Catamaran Brook and Little Southwest Miramichi River.

\begin{tabular}{|c|c|c|c|c|c|c|}
\hline \multirow[t]{2}{*}{ Study site } & \multirow[t]{2}{*}{$\begin{array}{c}\text { Drainage } \\
\text { area }\left(\mathrm{km}^{2}\right)\end{array}$} & \multirow[t]{2}{*}{$\begin{array}{l}\text { Width } \\
\text { (m) }\end{array}$} & \multirow[t]{2}{*}{ Depth (m) } & \multirow[t]{2}{*}{$\begin{array}{c}\text { Canopy } \\
\text { closure (\%) }\end{array}$} & \multicolumn{2}{|c|}{$\begin{array}{c}\text { Forest } \\
\text { composition (\%) }\end{array}$} \\
\hline & & & & & Hardwood & Softwood \\
\hline Little Southwest Miramichi River & 1190 & 80 & 0.52 & 20 & 70 & 30 \\
\hline Catamaran Brook & 27 & 9 & 0.16 & $55-65$ & 60 & 40 \\
\hline
\end{tabular}

\subsection{Modeling Performance Criteria}

To compare modeling performances of different years and study period (calibration/validation) three criteria were used: the root-mean-square error $(R M S E)$, the coefficient of determination $\left(R^{2}\right)$, and the bias (Bias). They were selected because they are often used in modeling studies and results from these performance criteria were also available for other water temperature models at CatBk and LSWM. The root-mean-square error (RMSE) represents the mean errors associated with the model. It was calculated using the following equation:

$$
R M S E=\sqrt{\frac{\sum_{i=1}^{N}\left(T_{w}(O)_{i}-T_{w}(P)_{i}\right)^{2}}{N}}
$$

Where $N$ is the number of hourly water temperature observations, $T_{w}(O)$ is the observed hourly water temperature and $T_{w}(P)$ is the predicted hourly water temperature.

The coefficient of determination $\left(R^{2}\right)$ represents the percentage of variability that can be explained by the model. It was calculated with the following formula:

$$
R^{2}=\left[\frac{N \sum_{i=1}^{N} T_{w}(O)_{i} T_{w}(P)_{i}-\left(\sum_{i=1}^{N} T_{w}(O)_{i}\right)\left(\sum_{i=1}^{N} T_{w}(P)_{i}\right)}{\sqrt{\left[N \sum_{i=1}^{N} T(O)_{i}^{2}-\left(\sum_{i=1}^{N} T_{w}(O)_{i}\right)^{2}\right] \times\left[N \sum_{i=1}^{N} T_{w}(P)_{i}^{2}-\left(\sum_{i=1}^{N} T_{w}(P)_{i}\right)^{2}\right]}}\right]^{2}
$$

The bias is an indication of the overestimation or underestimation of the water temperature model and represents the mean of errors calculated with the following equation:

$$
\text { Bias }=\frac{1}{N} \sum_{i=1}^{N}\left(T_{w}(P)_{i}-T_{w}(O)_{i}\right)
$$

\section{Results}

Before applying the equilibrium temperature model, the relationship between the air temperature and the equilibrium temperature was investigated. This was done by back calculating the total heat flux at the surface from observed water temperature variability. Results are shown in Figure 2 for both Catamaran Brook (CatBk) and Little Southwest Miramichi River (LSWM) using the 1998 data. A similar relationship was observed between air temperature and the equilibrium temperature at both sites. In CatBk, $63 \%$ of the variability of the hourly equilibrium temperature was explained by hourly air temperature (linear relation) whereas $73 \%$ of the variability was explained for LSWM. Given these good relationships between $T_{a}$ and $T_{e}$, the equilibrium temperature model was then applied to predict hourly water temperatures in a two-step process. The daily mean temperatures were predicted initially and then hourly temperatures were predicted. The equilibrium temperature was expressed as a function of air temperature, as presented in Equation (1). The coefficients $\alpha$ and $\beta$ were obtained by optimizing the minimum sum of squared differences between the hourly predicted and observed water temperatures for the calibration years (1998-2002). The linear regression coefficient $\alpha$ was calculated at $0.43^{\circ} \mathrm{C}$ for CatBk and a slightly higher value was obtained for LSWM $\left(0.54^{\circ} \mathrm{C}\right)$. The linear regression coefficient $\beta$ was $0^{\circ} \mathrm{C}$ for both studied watercourses. A constant thermal exchange $(K)$ was calculated with a value of $16.5 \mathrm{~W} \mathrm{~m}^{-2}{ }^{\circ} \mathrm{C}^{-1}$ at $\mathrm{CatBk}$ and of 72.0 $\mathrm{W} \mathrm{m}{ }^{-2}{ }^{\circ} \mathrm{C}^{-1}$ at LSWM. These parameters were then used to estimate hourly water temperatures using Equation 

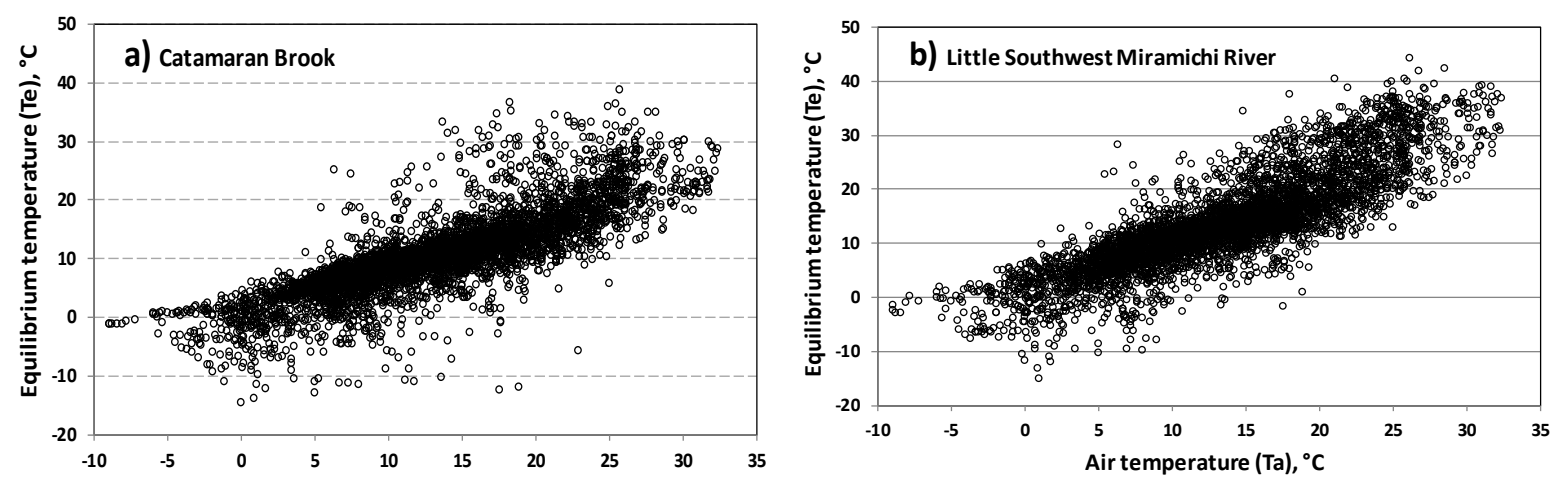

Figure 2. Relationship between observed equilibrium temperature $\left(T_{e}\right)$ and the air temperature $\left(T_{a}\right)$ at Catamaran Brook and Little Southwest Miramichi.

(1) during the validation period (years 2003-2007).

Figures 3-6 show predicted vs. observed water temperatures for each years at both CatBk and LSWM. Some years had days without data due to equipment malfunctions and were not included in the modeling. Figure 3 shows the calibration years at CatBk whereas Figure 4 shows the validation years. Results showed generally good agreement between predicted and observed water temperatures. However, a slight overestimation was observed at times during the spring (e.g., 2001, 2003 and 2007) and an underestimation was observed in summer (e.g., 2006) and in autumn (e.g., 2006). During some days, predicted water temperatures did not capture well the diel variation, as the equilibrium temperature model showed less diel variations than actual observed stream temperatures variations (e.g., day 170-185, 1999).

Results were similar for LSWM (Figure 5 and Figure 6). Spring water temperatures were also slightly overestimated in 2003 and 2005, similar to CatBk. Also, an important overestimation was also observed in LSWM in early summer 2006 (between day 130 and 165). In contrast, good agreement between predicted and observed temperatures was observed in late autumn at LSWM (unlike CatBk).

Table 2 shows the model performance of the equilibrium temperature model for the calibration years, the validation years, for each year and for all years. The model performance at CatBk was good during the calibration years $\left(R M S E=0.65^{\circ} \mathrm{C}, R^{2}=0.985\right.$ and Bias $\left.=0.00^{\circ} \mathrm{C}\right)$. The validation years still performed well with a $R M S E$ of $1.35^{\circ} \mathrm{C}$, a $R^{2}$ of 0.938 and a Bias of $-0.47^{\circ} \mathrm{C}$. The overall performance of the model was good $\left(R M S E=1.05^{\circ} \mathrm{C}, R^{2}\right.$ $=0.961$ and Bias $=-0.23^{\circ} \mathrm{C}$ ).

At LSWM, the calibration years showed equally good performance $\left(R M S E=0.65^{\circ} \mathrm{C}, R^{2}=0.990\right.$ and Bias $=$ $0.00^{\circ} \mathrm{C}$ ). The validation years at LSWM showed a poorer performance than the calibration period and poorer than CatBk, with a $R M S E$ of $1.82^{\circ} \mathrm{C}$, a $R^{2}$ of 0.911 and a Bias of $-0.13^{\circ} \mathrm{C}$. Overall, the LSWM showed a poorer performance (than CatBk) with an overall (all years) $R M S E$ of $1.36^{\circ} \mathrm{C}$ a $R^{2}$ of 0.954 and a Bias of $-0.06^{\circ} \mathrm{C}$.

A seasonal analysis was also performed to examine the performance of the model under different hydrometeorological conditions. Three seasons were selected (spring, summer and autumn), as defined previously. On a seasonal basis, the poorest performance of the model was in spring for both watercourses, except during the calibration years at LSWM, where the model performed similarly to other seasons. The spring performance at CatBkand LSWM during the validation showed $R M S E$ of $1.66^{\circ} \mathrm{C}(\mathrm{CatBk})$ and $1.98^{\circ} \mathrm{C}(\mathrm{LSWM})$, which were more than double the values observed during the calibration. At CatBk, the best performances during the validation period was in summer $\left(R M S E=1.14^{\circ} \mathrm{C} ; R^{2}=0.866 ;\right.$ Bias $\left.=-0.53^{\circ} \mathrm{C}\right)$. During the validation period, LSWM showed its best performance in autumn $\left(R M S E=1.45^{\circ} \mathrm{C} ; R^{2}=0.864 ;\right.$ Bias $\left.=-0.04^{\circ} \mathrm{C}\right)$. At $\mathrm{LSWM}$, the best overall (all years) performance was in autumn $\left(R M S E=1.05^{\circ} \mathrm{C}\right)$ whereas the best overall performance in CatBk was in summer $\left(R M S E=0.90^{\circ} \mathrm{C}\right)$ and autumn $\left(R M S E=0.97^{\circ} \mathrm{C}\right)$.

Four different time periods of 7 days were selected over the entire study period (1998-2007) to compare between observed $\left(T_{w}(O)\right)$ and predicted $\left(T_{w}(P)\right)$ hourly water temperatures as a function of air temperature $\left(T_{a}\right)$. They were selected to examine in more details the performance of the equilibrium temperature model under different meteorological and hydrological conditions. The selection of periods was made to include two calibration periods and two validation periods over the three seasons: spring, summer and autumn (Table 3). Results are presented in Figure 7. The two calibration periods consisted of 1) days in summer of 1998 (days 221 - 227) where 

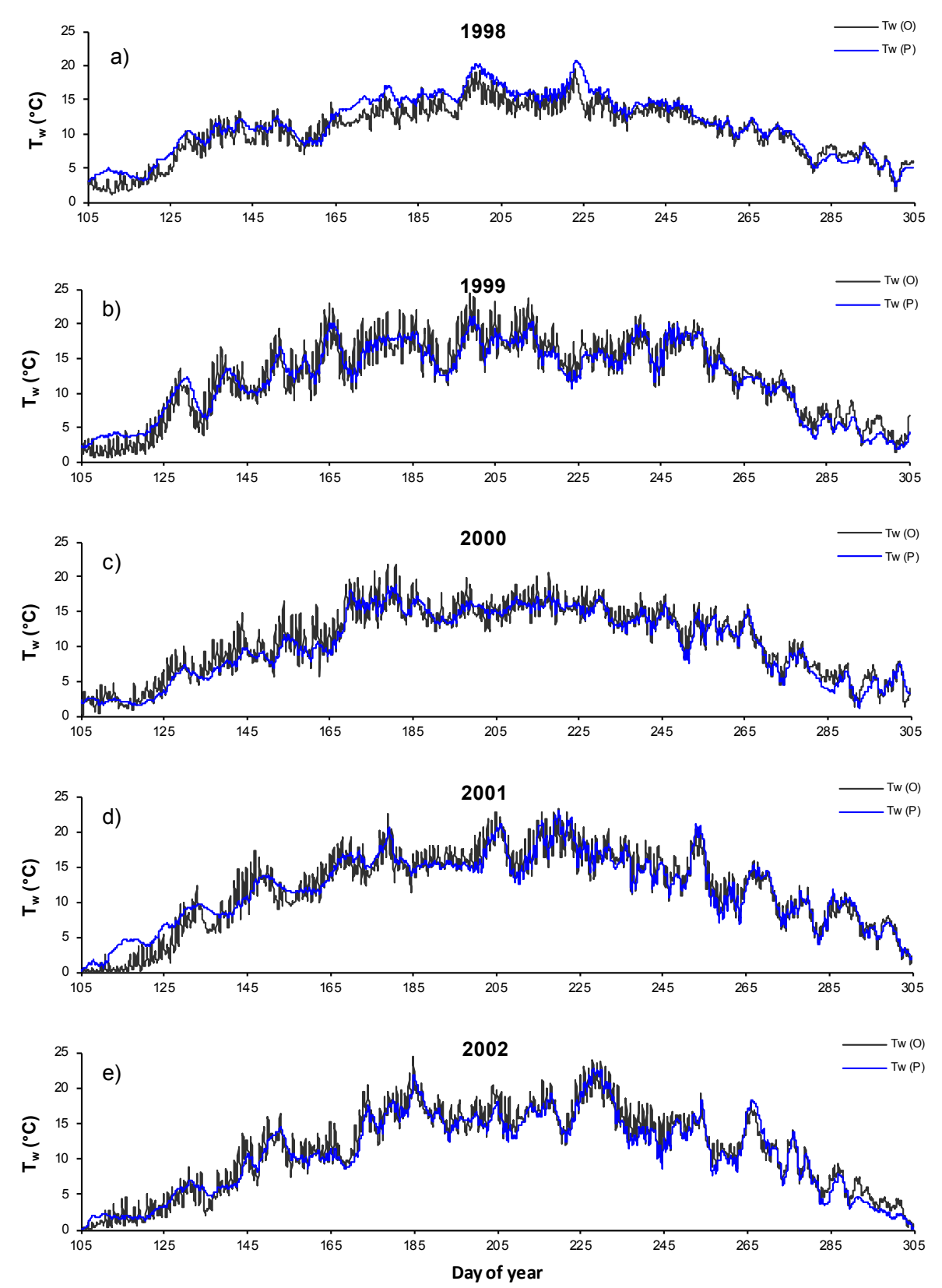

Figure 3. Observed water temperatures $\left(T_{w}(O)\right)$ and predicted water temperatures $\left(T_{w}(P)\right)$ obtained from the equilibrium temperature model at Catamaran Brook (calibration period).

a significant change in temperature was observed and 2) days in spring 1999 (days 132 - 138) where water temperatures increased rapidly. The two validation periods included 1) a period in autumn 2006 (days $292-298$ ) to reflect autumn conditions and 2) days in summer 2007, to study the model under high water temperature conditions (days 203 - 209).

In the first detailed period (calibration-1998; Figure 7(a) and Figure 7(b)), hourly air temperatures decreased rapidly from $31.7^{\circ} \mathrm{C}$ to $4.6^{\circ} \mathrm{C}$ at both CatBk and LSWM over a 5-day period. Predicted water temperatures for both watercourses effectively followed observed water temperatures, especially during days of rapid decrease in air and water temperatures. For the period during spring 1999 (Figure 7(c) and Figure 7(d)), air temperatures varied between $-3.5^{\circ} \mathrm{C}$ and $26.4^{\circ} \mathrm{C}$. Observed water temperatures varied similarly at both streams $\left(4.7^{\circ} \mathrm{C}\right.$ to $18.2^{\circ} \mathrm{C}$ ). Predicted water temperatures at CatBk showed a general increasing trend; however the model was not 

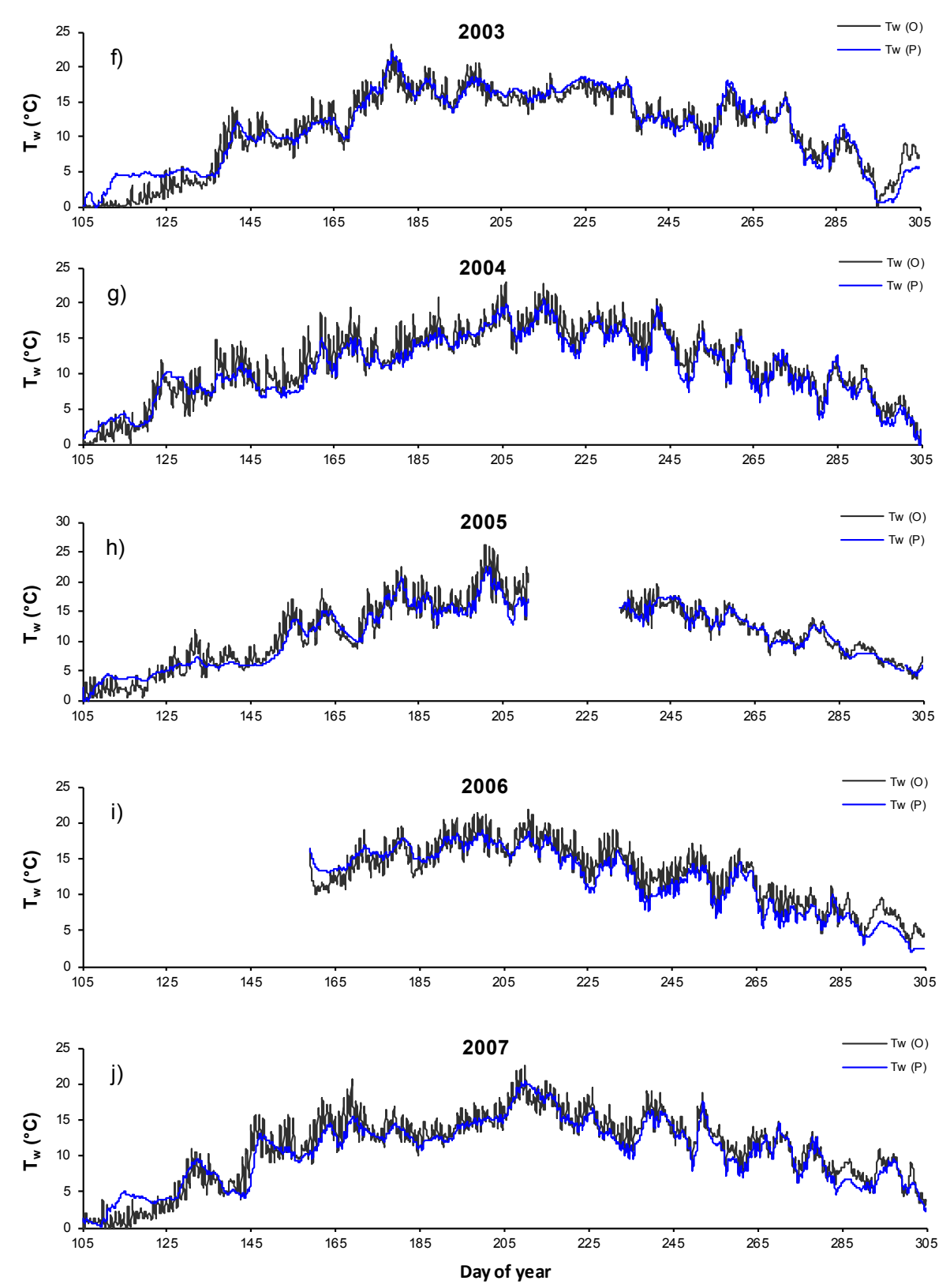

Figure 4. Observed water temperatures $\left(T_{w}(O)\right)$ and predicted water temperatures $\left(T_{w}(P)\right)$ obtained from the equilibrium temperature model at Catamaran Brook (validation period).

able to fully capture the diel variability in observed water temperatures. In contrast, the model was better able to capture the diel variability of water temperatures at LSWM during the same period. Predicted water temperatures varied from $5.3^{\circ} \mathrm{C}$ to $14.0^{\circ} \mathrm{C}$ at $\mathrm{CatBk}$, and were higher at LSWM, varying between $5.4^{\circ} \mathrm{C}$ and $16.9^{\circ} \mathrm{C}$. Air and water temperatures were low during the period of autumn 2006 (Figure 7(e) and Figure 7(f)). Air temperatures were higher in the first 3 days, and decreased slightly afterwards $\left(2.4^{\circ} \mathrm{C}\right.$ to $\left.12.0^{\circ} \mathrm{C}\right)$. Water temperatures did not show much diel variability during those days. In fact, water temperatures slightly varied between $4.6^{\circ} \mathrm{C}$ and $6.5^{\circ} \mathrm{C}$ at both CatBk and LSWM. Predicted water temperatures at CatBk did not truly represent observed water temperatures, with values ranging between $4.4^{\circ} \mathrm{C}$ and $6.3^{\circ} \mathrm{C}$. At LSWM, predicted water temperatures showed a better agreement with observed water temperatures, between $5.8^{\circ} \mathrm{C}$ and $8.9^{\circ} \mathrm{C}$. The period during the summer 2007 included warm air and water temperatures (Figure 7(g) and Figure 7(h)). In fact, air temperatures increased from $6.9^{\circ} \mathrm{C}$ to reach $31.6^{\circ} \mathrm{C}$ towards the end of the period. Observed water temperatures at $\mathrm{CatBk}\left(13.6^{\circ} \mathrm{C}\right.$ to $\left.22.4^{\circ} \mathrm{C}\right)$ 

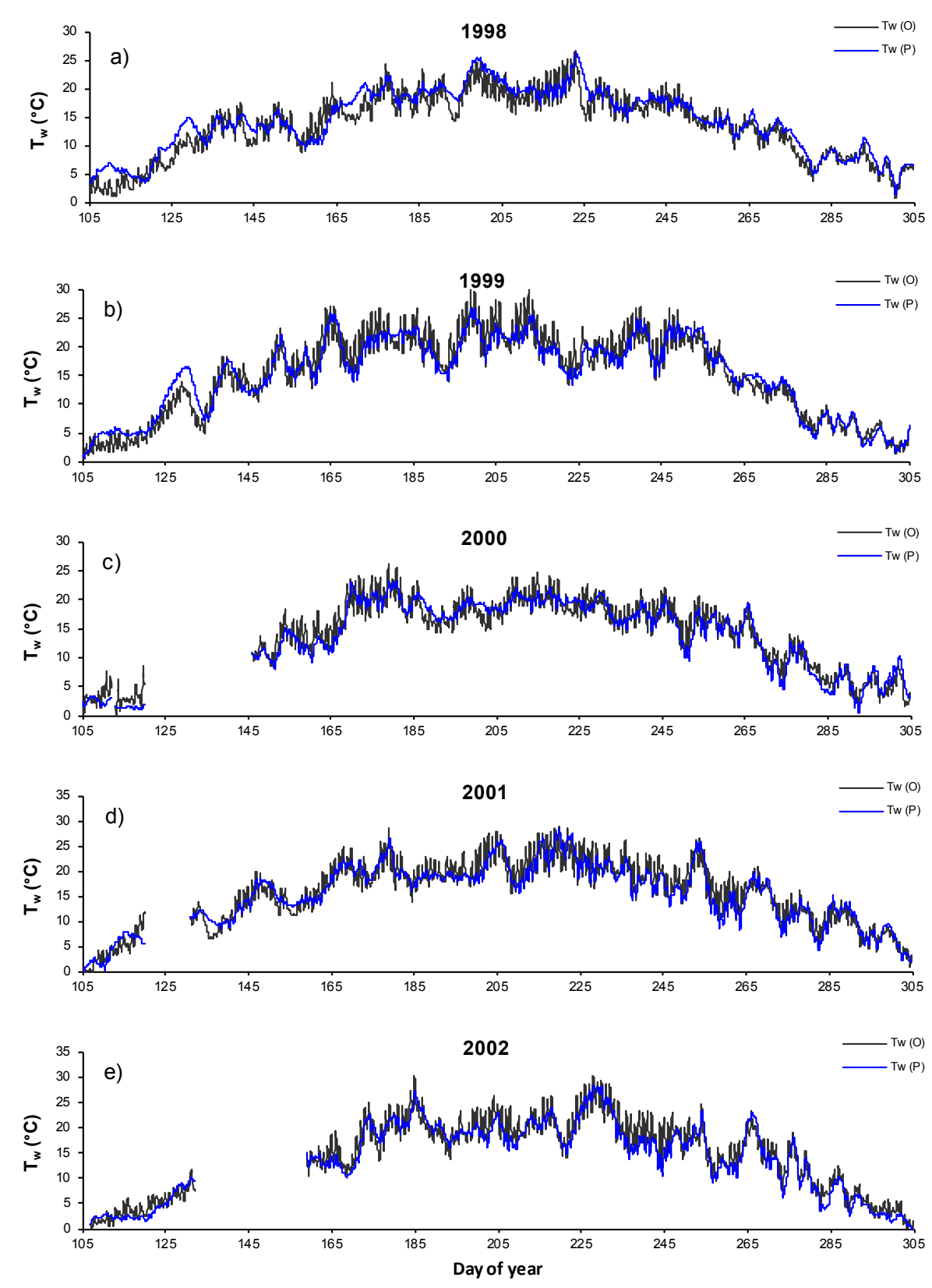

Figure 5. Observed water temperatures $\left(T_{w}(O)\right)$ and predicted water temperatures $\left(T_{w}(P)\right)$ obtained from the equilibrium temperature model at Little Southwest Miramichi River (calibration period).

varied similarly as in $\operatorname{LSWM}\left(16.8^{\circ} \mathrm{C}\right.$ to $\left.28.9^{\circ} \mathrm{C}\right)$. Predicted water temperatures showed a general increasing trend; however, the diel variability was not well captured by the model. Water temperatures varied between $13.3^{\circ} \mathrm{C}$ and $20.6^{\circ} \mathrm{C}$ at $\mathrm{CatBk}$, and between $16.4^{\circ} \mathrm{C}$ and $27.1^{\circ} \mathrm{C}$ at LSWM.

\section{Discussion}

Deterministic models have been shown to be an effective tool in predicting stream water temperatures [20] [22], but require a lot of input data. An equilibrium temperature model was developed to predict hourly water temperatures, assuming that total heat flux was proportional to the difference between the hourly water temperature and an hourly equilibrium temperature [14]. Moreover, hourly equilibrium temperatures were linearly related to hourly 

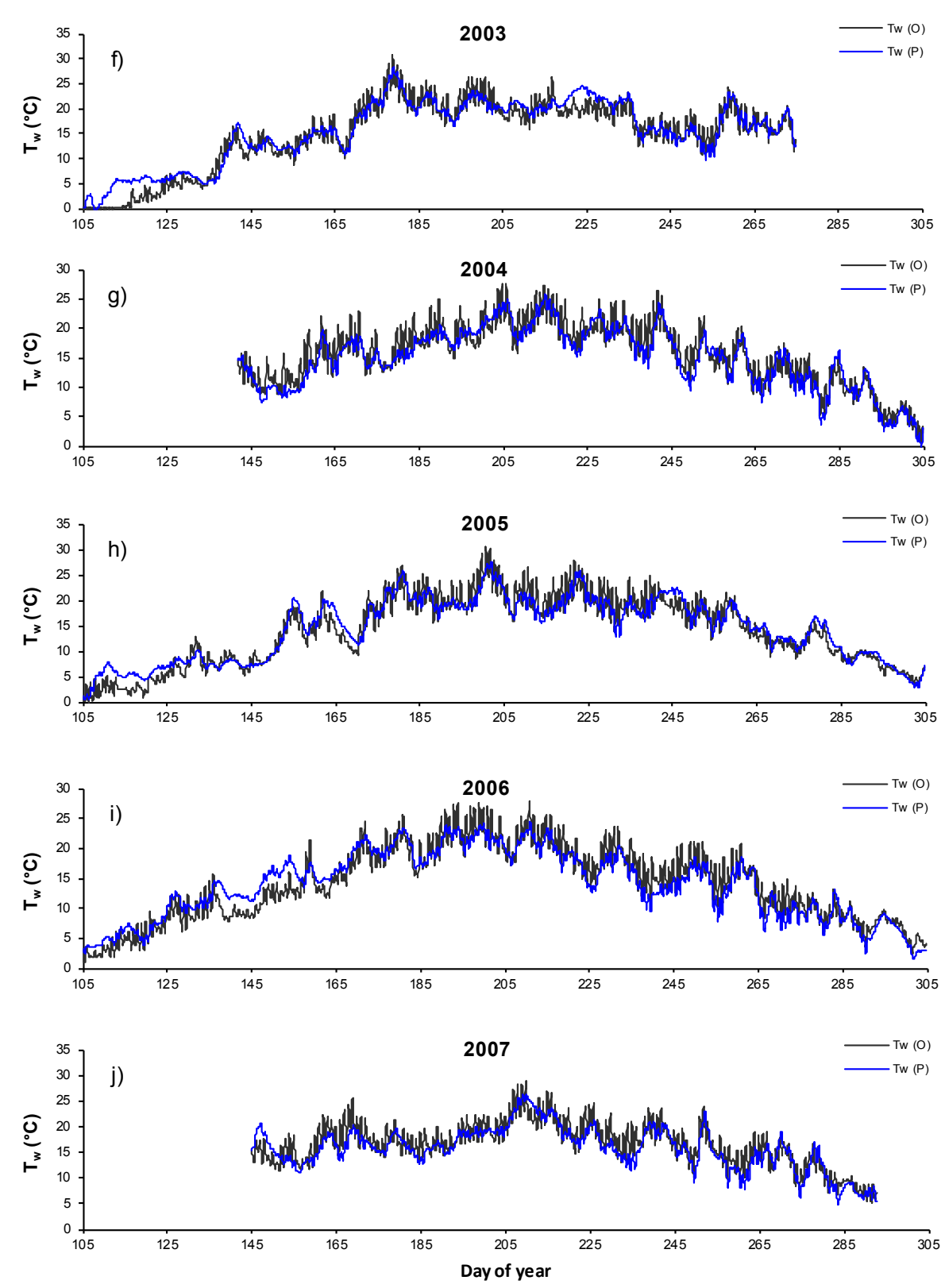

Figure 6. Observed water temperatures $\left(T_{w}(O)\right)$ and predicted water temperatures $\left(T_{w}(P)\right)$ obtained from the equilibrium temperature model at Little Southwest Miramichi River (validation period).

air temperatures. The equilibrium temperature model applied in the present study only requires hourly air temperature and water level to predict river temperatures [15]. Most equilibrium temperature models are developed to study the thermal regime of rivers [16] [26] [27], but few have been used to model long-term time series of water temperatures [15] [19]. For a daily time scale, studies have shown that daily mean air temperatures are highly related to daily equilibrium temperatures, permitting the expression of equilibrium temperature as a linear function of air temperature [15] [19].

Results for the present study show that hourly equilibrium temperatures are also related to hourly air temperatures although some scatter is observed (Figure 2). In fact, $63 \%-73 \%$ of the variability of the equilibrium temperature was explained by air temperature. The coefficients $(\alpha$ and $\beta)$ of the linear relationship between hourly air and equilibrium temperature were then calculated. In the present study the coefficient $\beta$ was calculated at zero. 
Table 2. Results of the equilibrium temperature model for the prediction of hourly water temperatures at Catamaran Brook and Little Southwest Miramichi River.

\begin{tabular}{|c|c|c|c|c|c|c|}
\hline \multirow[b]{2}{*}{ Period } & \multicolumn{3}{|c|}{ Catamaran Brook } & \multicolumn{3}{|c|}{ Little Southwest Miramichi } \\
\hline & $\operatorname{RMSE}\left({ }^{\circ} \mathrm{C}\right)$ & $R^{2}$ & $\operatorname{Bias}\left({ }^{\circ} \mathrm{C}\right)$ & $\operatorname{RMSE}\left({ }^{\circ} \mathrm{C}\right)$ & $R^{2}$ & $\operatorname{Bias}\left({ }^{\circ} \mathrm{C}\right)$ \\
\hline Calibration (1998-2002) & 0.65 & 0.985 & 0.00 & 0.65 & 0.990 & 0.00 \\
\hline 1998 & 0.42 & 0.989 & 0.00 & 0.49 & 0.992 & 0.00 \\
\hline 1999 & 0.73 & 0.83 & 0.00 & 0.61 & 0.993 & 0.00 \\
\hline 2000 & 0.68 & 0.981 & 0.00 & 0.72 & 0.987 & 0.00 \\
\hline 2001 & 0.72 & 0.983 & 0.00 & 0.73 & 0.987 & 0.00 \\
\hline 2002 & 0.64 & 0.988 & 0.00 & 0.69 & 0.991 & 0.00 \\
\hline Validation (2003-2007) & 1.35 & 0.938 & -0.47 & 1.82 & 0.911 & -0.13 \\
\hline 2003 & 1.33 & 0.943 & 0.13 & 1.58 & 0.953 & 0.40 \\
\hline 2004 & 1.28 & 0.953 & -0.71 & 1.84 & 0.891 & -0.56 \\
\hline 2005 & 1.31 & 0.948 & -0.37 & 2.04 & 0.910 & 0.25 \\
\hline 2006 & 1.44 & 0.932 & -0.89 & 1.70 & 0.924 & -0.15 \\
\hline 2007 & 1.40 & 0.937 & -0.63 & 1.95 & 0.815 & -0.67 \\
\hline \multirow[t]{2}{*}{ All years (1998-2007) } & 1.05 & 0.961 & -0.23 & 1.36 & 0.954 & -0.06 \\
\hline & \multicolumn{6}{|c|}{ Seasonal analysis } \\
\hline \multicolumn{7}{|l|}{ Calibration (1998-2002) } \\
\hline Spring & 0.80 & 0.972 & 0.00 & 0.66 & 0.988 & 0.01 \\
\hline Summer & 0.60 & 0.949 & 0.00 & 0.68 & 0.960 & 0.00 \\
\hline Autumn & 0.45 & 0.980 & 0.00 & 0.58 & 0.982 & 0.00 \\
\hline \multicolumn{7}{|l|}{ Validation (2003-2007) } \\
\hline Spring & 1.66 & 0.906 & -0.24 & 1.98 & 0.884 & 0.46 \\
\hline Summer & 1.14 & 0.866 & -0.53 & 1.86 & 0.743 & -0.47 \\
\hline Autumn & 1.30 & 0.870 & -0.64 & 1.45 & 0.864 & -0.04 \\
\hline \multicolumn{7}{|l|}{ All years (1998-2007) } \\
\hline Spring & 1.27 & 0.935 & -0.11 & 1.46 & 0.937 & 0.23 \\
\hline Summer & 0.90 & 0.897 & -0.27 & 1.40 & 0.840 & -0.23 \\
\hline Autumn & 0.97 & 0.871 & -0.32 & 1.05 & 0.937 & -0.02 \\
\hline
\end{tabular}

Table 3. Description of the four selected study periods to examine the performance of the water temperature model under different meteorological and hydrological conditions.

\begin{tabular}{cccccc}
\hline Sample & Season & Year & Day of year & Date & Hydrological conditions \\
\hline Calibration & Summer & 1998 & $221-227$ & 9 August-15 August & Rapid decrease in air and water temperatures \\
Calibration & Spring & 1999 & $132-138$ & 12 May-18 May & Gradual increase in air and water temperatures \\
Validation & Autumn & 2006 & $292-298$ & 19 October-25 October & Autumn conditions \\
Validation & Summer & 2007 & $203-209$ & 22 July-29 July & Warm air temperature conditions \\
\hline
\end{tabular}

Therefore, both $\alpha$ and $K$ of the equilibrium temperature model reflected the total heat flux at the surface. The coefficient $\alpha$ was calculated at 0.43 at CatBk and 0.54 at LSWM. The calibration coefficient $(\alpha)$ calculated within the present study for hourly temperatures was slightly lower than those found in studies using the equilibrium temperature concept at daily time scales. For example, Caissie et al. [15] calibrated both the same study streams with coefficient $\alpha$ at 0.81 at CatBk and of 1.05 at LSWM (for daily time scale). Marcé and Armengol [28] found the coefficient $\alpha$ varying in the range of 0 to 2 whereas Larnier et al. [19] found a coefficient $\alpha$ of 1.12 similar to LSWM (daily time step). These differences are most likely due to the different time scales. The coefficient $\beta$ was calibrated at $0^{\circ} \mathrm{C}$, similar to Caissie et al. [15]. However, other studies have shown values of $\beta$ at $0.44^{\circ} \mathrm{C}$ [19] and $-10^{\circ} \mathrm{C}$ to $45^{\circ} \mathrm{C}[28]$.

The thermal exchange coefficient $K$ was calculated at $16.5 \mathrm{~W} \mathrm{~m}^{-2}{ }^{\circ} \mathrm{C}^{-1}$ (CatBk) and at $72.0 \mathrm{~W} \mathrm{~m}^{-2}{ }^{\circ} \mathrm{C}^{-1}$ (LSWM). Caissie et al. [15], who also studied the two same rivers, but at a daily time scale, observed lower ther- 
Catamaran Brook
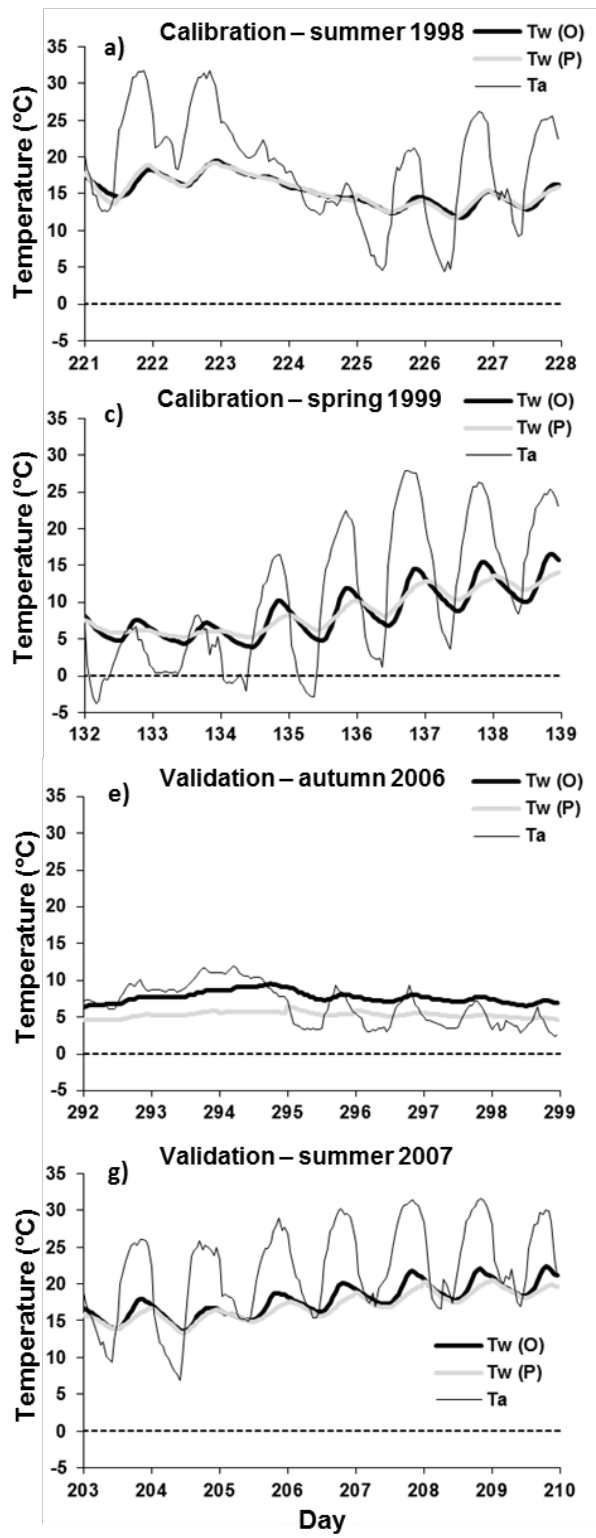

Little Southwest Miramichi
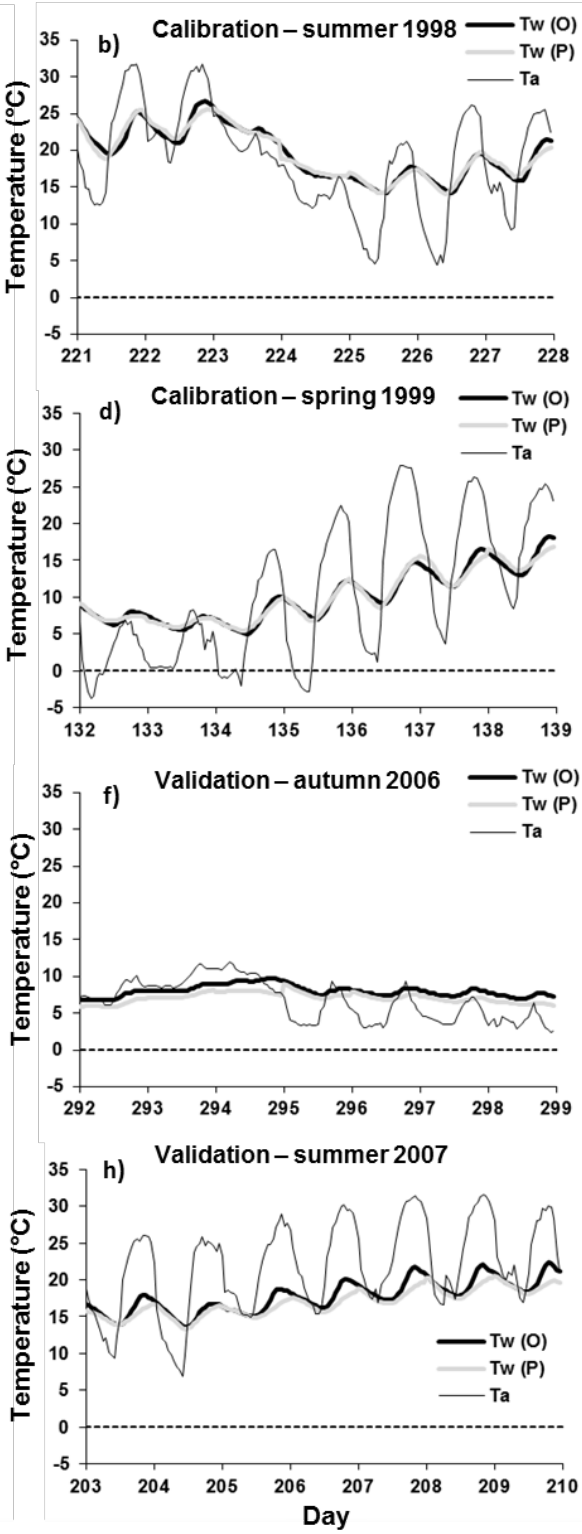

Figure 7. Observed water temperatures $\left(T_{w}(O)\right)$, predicted water temperatures $\left(T_{w}(P)\right)$ from the equilibrium temperature model and air temperatures $\left(T_{a}\right)$ for the four detailed time periods at Catamaran Brook and Little Southwest Miramichi River.

mal exchange coefficient $K\left(6.3 \mathrm{~W} \mathrm{~m}^{-2}{ }^{\circ} \mathrm{C}^{-1}\right.$ at $\mathrm{CatBk}$ and $29.1 \mathrm{~W} \mathrm{~m}^{-2}{ }^{\circ} \mathrm{C}^{-1}$ at $\left.\mathrm{LSWM}\right)$. These differences suggest that the time scale is an important factor in the estimation of $K$. Larnier et al. [19] showed results closer to the LSWM values with a thermal exchange coefficient $K$ of $34.4 \mathrm{~W} \mathrm{~m}^{-2}{ }^{\circ} \mathrm{C}^{-1}$. Marcé and Armengol [28] showed thermal exchange coefficients ranging from $0 \mathrm{~W} \mathrm{~m}^{-2}{ }^{\circ} \mathrm{C}^{-1}$ to $23.3 \mathrm{~W} \mathrm{~m}^{-2}{ }^{\circ} \mathrm{C}^{-1}$. Herb and Stefan [29] calculated a thermal exchange coefficient close to the one calculated at Catamaran Brook in this study. For example, the South Branch (Minnesota, USA) had a thermal exchange coefficient $K$ of $9.0 \mathrm{~W} \mathrm{~m}^{-2}{ }^{\circ} \mathrm{C}^{-1}$ and the main stream had a coefficient $K$ of $13.1 \mathrm{~W} \mathrm{~m}^{-2}{ }^{\circ} \mathrm{C}^{-1}$. The hourly exchange coefficients $K$ found in this study were higher than values estimated during studies of daily mean water temperatures; however, the coefficient $\alpha$ was smaller. It is worth noting that the total heat flux by the equilibrium temperature model is calculated through a combination of these two coefficients (Equation (1)) as well as the difference between $T_{e}$ and $T_{w}$.

The thermal exchange coefficient $K$ and the difference between $T_{e}$ and $T_{w}$ represent the bulk surface heat flux. 
Previous studies have shown that the thermal exchange coefficient is generally a function of many meteorological parameters [14] [16]; however, other studies achieve good results by assuming a constant $K$ throughout the years [15] [19]. The thermal exchange coefficient $K$ affects the rate at which water temperature changes. A high value of $K$ will correspond to higher rates of change for similar temperature differences $\left(T_{e}-T_{w}\right)$ and vice versa. These quantities will also be a function of time scales (e.g., $\Delta T$ on daily or hourly basis). Other processes (than surface heat fluxes, e.g., streambed, depth, etc.) can affect the rate of change of water temperatures. In the present study, CatBk $\left(K=16.5 \mathrm{~W} \mathrm{~m}^{-2}{ }^{\circ} \mathrm{C}^{-1}\right)$ showed a lower $K$ value than LSWM $\left(K=72.0 \mathrm{~W} \mathrm{~m}^{-2}{ }^{\circ} \mathrm{C}^{-1}\right)$, suggesting lower water temperature variability for similar temperature differences $\left(T_{e}-T_{w}\right)$, because $\alpha$ was somewhat similar between CatBk and LSWM. CatBk is more sheltered by streamside vegetation, having a greater groundwater contribution. These factors can also be contributed to less water temperature variability in CatBk.

The coefficient $K$ was assumed constant throughout the year in the equilibrium temperature model, as applied in other studies [15] [19]. A sensitivity analysis $( \pm 5 \%-10 \%)$ of the thermal exchange coefficient $K$ showed changes of less than $\pm 0.02^{\circ} \mathrm{C}$ in hourly stream temperatures when applied during the whole study period (i.e. 15 April to 31 October). However, does the value of $K$ vary seasonally? Another sensitivity analysis was carried out by calibrating the model for the month of April to October, and determining the best $K$ value to fit the data for each month. Results of this analysis are shown in Table 4 for both studied watercourses. The months of July and August had coefficients $K$ closest to the values observed annually $\left(16.5 \mathrm{~W} \mathrm{~m}^{-2}{ }^{\circ} \mathrm{C}^{-1} \mathrm{CatBk}\right.$ and $72.0 \mathrm{~W} \mathrm{~m}^{-2}{ }^{\circ} \mathrm{C}^{-1}$ LSWM). The monthly calibration of the thermal exchange coefficient showed high values of $K$ in the spring followed by low values in summer and autumn months. These results suggest that $K$ may be a function of water levels, where higher coefficients are required in the spring for similar $T_{e}-T_{w}$ variability. The month of April showed the highest value of $K$ at both CatBk $\left(98.8 \mathrm{~W} \mathrm{~m}^{-2}{ }^{\circ} \mathrm{C}^{-1}\right)$ and $\operatorname{LSWM}\left(171.5 \mathrm{~W} \mathrm{~m}^{-2}{ }^{\circ} \mathrm{C}^{-1}\right)$. The low value of $K$ in autumn could also be related to the fact that smaller diel variability was observed in both air and water temperature during this period.

Overall, the RMSEs obtained with the equilibrium temperature model were similar to those observed in previous studies [15] [19] [29], with an overall $R M S E$ of $1.05^{\circ} \mathrm{C}$ at CatBk and $1.36^{\circ} \mathrm{C}$ at LSWM. Most equilibrium temperature models in previous studies were developed to predict daily water temperatures. Herb and Stefan [29] estimated daily average stream temperatures with a $R M S E$ of $1.2^{\circ} \mathrm{C}$ for a small tributary and of $1.4^{\circ} \mathrm{C}$ for a larger stream. Marcé and Armengol [28] observed similar RMSEs to CatBk, around $1.40^{\circ} \mathrm{C}$. Larnier et al. [19] calculated $R M S E s$ of $1.22^{\circ} \mathrm{C}$ (calibration) and $1.31^{\circ} \mathrm{C}$ (validation). Caissie et al. [15] applied the same equilibrium temperature model in the present study in both CatBk and LSWM (at a daily time scale), and showed RMSEs of $1.21^{\circ} \mathrm{C}$ (CatBk) and $1.52^{\circ} \mathrm{C}$ (LSWM).

A seasonal analysis was performed for both CatBk and LSWM for three seasons: spring (15 April to 20 June), summer (21 June to 20 September) and autumn (21 September to 31 October; Table 2). This analysis showed that the best performance of the equilibrium temperature model was during autumn and the poorest performance was in spring. These results are consistent with those of other water temperature modeling studies [30] [31]. Snowmelts conditions in spring can influence the relationship between air and water temperatures. The atmospheric energy in spring is contributed mainly to the snowmelt and soil heating processes, therefore the water temperatures are not following rapid increases similar to air temperatures. Autumn showed better predictions of water temperatures, presumably due to lower water levels usually observed during the year and a more effective heat exchange between the river and its heat sources.

Table 4. The values of the thermal exchange coefficient $(K)$ calibrated for each month (April to October) at both Catamaran Brook and Little Southwest Miramichi River.

\begin{tabular}{ccc}
\hline Month & Catamaran Brook \\
& $K\left(\mathrm{~W} \mathrm{~m} \mathrm{~m}^{-2}{ }^{\circ} \mathrm{C}^{-1}\right)$ & \multicolumn{2}{c}{ Little Southwest Miramichi River } \\
April & 98.8 & $\left.\mathrm{~W} \mathrm{~m}^{-2}{ }^{\circ} \mathrm{C}^{-1}\right)$ \\
May & 40.2 & 171.5 \\
June & 19.1 & 74.1 \\
July & 15.9 & 80.8 \\
August & 13.2 & 78.0 \\
September & 10.0 & 67.5 \\
October & 10.4 & 58.7 \\
\hline
\end{tabular}


One useful aspect in predicting hourly water temperatures, especially from an aquatic habitat perspective, is that daily minimum, maximum and daily mean water temperature can be obtained from the modeling. Predicted hourly water temperatures were used to calculate daily maximum $\left(T_{\max }\right)$ and daily mean water temperatures $\left(T_{\text {mean }}\right)$ (Table 5). The performance of the daily mean water temperatures was better than the hourly water temperatures. The RMSE for all years was of $0.83^{\circ} \mathrm{C}$ at CatBk and $0.97^{\circ} \mathrm{C}$ at LSWM. The coefficient of determination $R^{2}$ was 0.975 at both study streams. These results were also comparable to other studies where the equilibrium temperature model was used to predict daily water temperatures [15]. Daily maximum water temperatures have shown to have important influences on biological conditions [3] [32]. The predicted hourly water temperatures were also used to calculate the daily maximum water temperatures $\left(T_{\max }\right)$ (Table 5 ). The equilibrium temperature model was effectively in predicting daily maximum water temperatures with a RMSE of $1.3^{\circ} \mathrm{C}$ for both watercourses. Different factors can influence daily maximum water temperatures. Among them is the evaporative cooling, which has been shown to affect the relationship between air and stream temperatures, especially at high temperatures [16]. For example, studies have shown that the relationship between air and stream temperature differed from linearity at air temperatures over $25^{\circ} \mathrm{C}$, where water temperature does not increase at the same rate as air temperature [16] [33].

A comparison of observed vs. predicted daily mean $\left(T_{\text {mean }}\right)$ and daily maximum $\left(T_{\max }\right)$ water temperatures was done for both CatBk and LSWM based on hourly data from the equilibrium temperature model (Figure 8). A good agreement was observed between predicted and observed daily mean water temperatures with $R^{2}$ of 0.975 at both CatBk and LSWM. For daily maximum water temperatures, a $R^{2}$ of 0.957 (CatBk) and 0.967 (LSWM) was observed.

River water temperatures are predicted in the range of $1.0^{\circ} \mathrm{C}$ to $1.4^{\circ} \mathrm{C}$ in modeling studies [21] [30] [34]. The present study shows that representing the equilibrium temperature using air temperature was effective in predict-
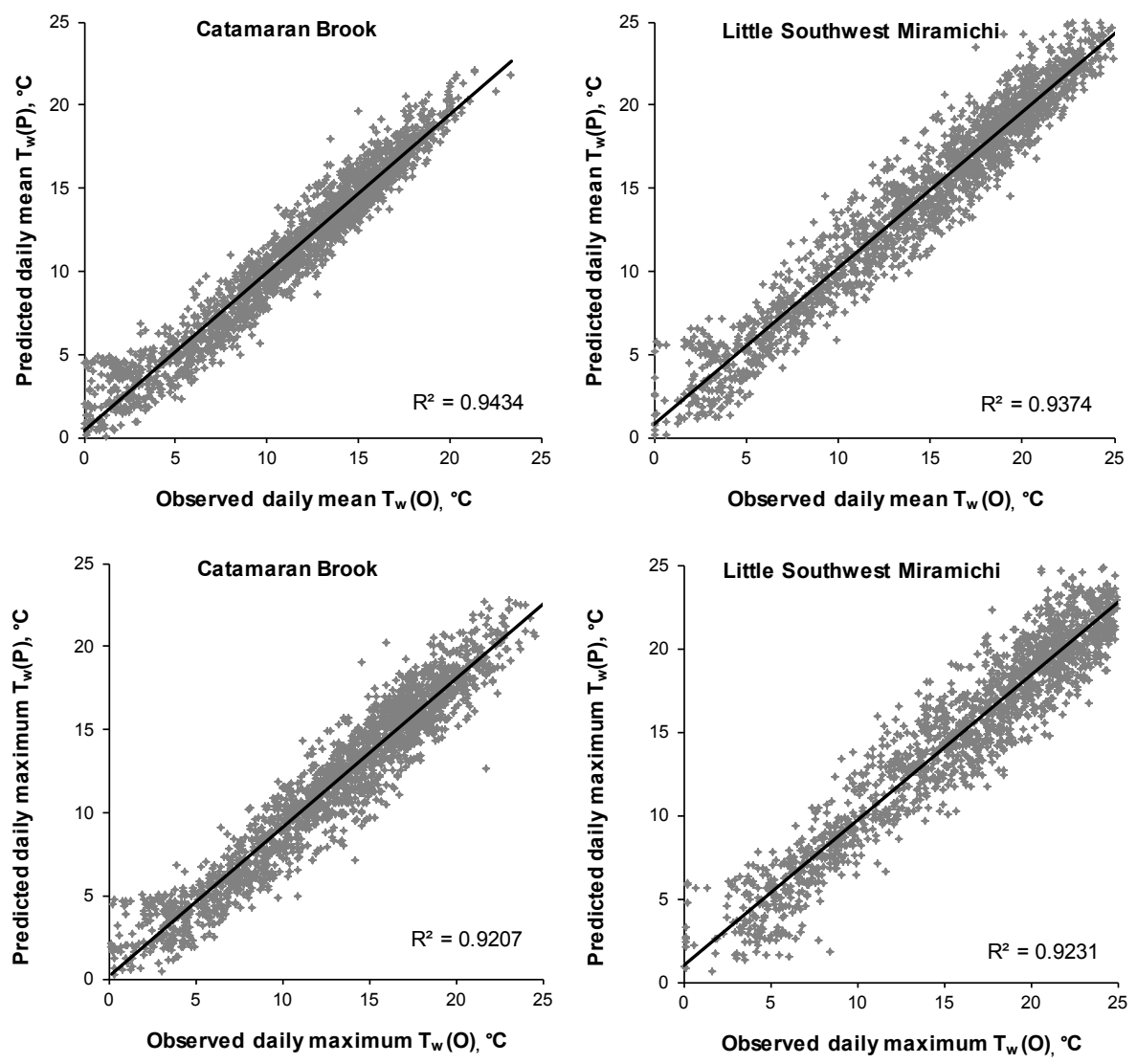

Figure 8. Predicted $\left(T_{\text {mean }}(P)\right)$ versus observed daily mean water temperatures $\left(T_{\text {mean }}(O)\right)$ and predicted $\left(T_{\max }(P)\right)$ versus observed daily maximum water temperatures $\left(T_{\max }(O)\right)$ at Catamaran Brook and Little Southwest Miramichi, with the equilibrium temperature model. 
Table 5. Results of the daily mean $\left(T_{\text {mean }}\right)$ and daily maximum $\left(T_{\max }\right)$ stream temperature calculated from the predicted hourly water temperatures (equilibrium temperature model) at Catamaran Brook and Little Southwest Miramichi River.

\begin{tabular}{cccccccc}
\hline & & \multicolumn{3}{c}{ Catamaran Brook } & \multicolumn{3}{c}{ Little Southwest Miramichi River } \\
\hline \multirow{2}{*}{$\mathrm{T}_{\mathrm{w}}$} & Period & $R M S E$ & $R^{2}$ & Bias & $R M S E$ & $R^{2}$ & Bias \\
\hline \multirow{2}{*}{ Daily mean $T_{\text {mean }}\left({ }^{\circ} \mathrm{C}\right)$} & Calibration (1998-2002) & 0.01 & 1.00 & 0.00 & 0.01 & 1.00 & 0.00 \\
& Validation (2003-2007) & 1.20 & 0.950 & -0.48 & 1.40 & 0.944 & -0.12 \\
& All years (1998-2007) & 0.83 & 0.975 & -0.23 & 0.97 & 0.975 & -0.06 \\
Daily maximum $T_{\max }\left({ }^{\circ} \mathrm{C}\right)$ & Calibration (1998-2002) & 0.86 & 0.981 & -0.40 & 0.79 & 0.989 & -0.26 \\
& Validation (2003-2007) & 1.61 & 0.930 & -0.80 & 1.66 & 0.940 & -0.19 \\
& All years (1998-2007) & 1.28 & 0.957 & -0.59 & 1.29 & 0.967 & -0.22 \\
\hline
\end{tabular}

ing hourly water temperatures. Although the model performed well, it did not fully capture the diel variability in some cases. As such, other important fluxes and parameters may be required to achieve a better modeling performance. For instance, the relationship between equilibrium and stream temperature can also be affected by factors such as wind sheltering, stream shading, groundwater inputs or artificial heat inputs. However, including more input variables into the equilibrium temperature model will ultimately make the model more complex and closer to a true deterministic model, which is not the objective of the current modeling approach.

In the present study, the equilibrium temperature model showed relatively good performance. The RMSEs were similar to those of other studies with $R M S E$ of $1.05^{\circ} \mathrm{C}$ (CatBk) and $1.36^{\circ} \mathrm{C}$ (LSWM). These results suggest that the air (and corresponding equilibrium temperature) adequately reflected the total heat flux at the water surface. The model's best performance was in autumn and late summer, where the low water levels permitted more efficient thermal exchange. In contrast, the presence of snowmelt conditions in spring resulted in poorer performance. The predicted hourly water temperatures were used to estimate the daily mean and maximum water temperatures. The results of the daily mean water temperatures were comparable or better to other equilibrium temperature results on a daily basis [15]. The daily maximum water temperatures were also well predicted but had higher RMSEs. Modeling of water temperature remains a very useful tool in the management of fisheries and aquatic resources.

\section{Acknowledgements}

We would like to acknowledge the Natural Sciences and Engineering Research Council of Canada for funding the present research.

\section{References}

[1] Caissie, D. (2006) The Thermal Regime of Rivers: A Review. Freshwater Biology, 51, 1389-1406. http://dx.doi.org/10.1111/j.1365-2427.2006.01597.x

[2] Webb, B.W., Hannah, D.M., Moore, R.D., Brown, L.E. and Nobilis, F. (2008) Recent Advances in Stream and River Temperature Research. Hydrological Processes, 22, 902-918. http://dx.doi.org/10.1002/hyp.6994

[3] Breau, C., Cunjak, R.A. and Bremset, G. (2007) Age-Specific Aggregation of Wild Juvenile Atlantic Salmon Salmo salar at Cool Water Sources during High Temperature Events. Journal of Fish Biology, 71, 1179-1191. http://dx.doi.org/10.1111/j.1095-8649.2007.01591.x

[4] Raphael, J.M. (1962) Prediction of Temperature in Rivers and Reservoirs. Journal of the Power Division, 88, $157-181$.

[5] Brown, G.W. (1969) Predicting Temperatures of Small Streams. Water Resources Research, 5, 68-75. http://dx.doi.org/10.1029/WR005i001p00068

[6] Markarian, R.K. (1980) A Study of the Relationship between Aquatic Insect Growth and Water Temperature in a Small Stream. Hydrobiologia, 75, 81-95. http://dx.doi.org/10.1007/BF00006565

[7] Wichert, G.A. and Lin, P. (1996) A Species Tolerance Index of Maximum Water Temperature. Water Quality Resources Journal of Canada, 31, 875-893.

[8] Kinouchi, T., Yagi, H. and Miyamoto, M. (2007) Increase in Stream Temperature Related to Anthropogenic Heat Input from Urban Wastewater. Journal of Hydrology, 335, 78-88. http://dx.doi.org/10.1016/j.jhydrol.2006.11.002

[9] Bradley, A.A., Holly, F.M., Walker, W.K. and Wright, S.A. (1998) Estimation of Water Temperature Exceedance Probabilities Using Thermo-Hydrodynamic Modeling. Journal of the American Water Association, 34, 467-480. 
http://dx.doi.org/10.1111/j.1752-1688.1998.tb00947.x

[10] Moore, R.D., Spittlehouse, D.L. and Story, A. (2005) Riparian Microclimate and Stream Temperature Response to Forest Harvesting: A Review. Journal of the American Water Resources Association, 41, 813-834.

[11] Morrison, J., Quick, M.C. and Foreman, M.G.G. (2002) Climate Change in the Fraser River Watershed: Flow and Temperature Projections. Journal of Hydrology, 263, 230-244. http://dx.doi.org/10.1016/S0022-1694(02)00065-3

[12] Tung, C.P., Lee, T.Y. and Yang, Y.C. (2006) Modeling Climate-Change Impacts on Stream Temperature of Formosan Landlocked Salmon Habitat. Hydrological Processes, 20, 1629-1649. http://dx.doi.org/10.1002/hyp.5959

[13] Morin, G. and Couillard, D. (1990) Predicting River Temperatures with a Hydrological Model. In: Cheremisinoff, N.P., Ed., Encyclopedia of Fluid Mechanic, Surface and Groundwater Flow Phenomena, Gulf Publishing Company, Houston, Vol. 10, 171-209.

[14] Edinger, J.E., Duttweiler, D.W. and Geyer, J.C. (1968) The Response of Water Temperatures to Meteorological Conditions. Water Resources Research, 4, 1137-1143. http://dx.doi.org/10.1029/WR004i005p01137

[15] Caissie, D., Satish, M.G. and El-Jabi, N. (2005) Predicting River Water Temperatures Using the Equilibrium Temperature Concept Method with Applications on Miramichi River Catchments (New Brunswick, Canada). Hydrological Processes, 19, 2137-2159. http://dx.doi.org/10.1002/hyp.5684

[16] Mohseni, O. and Stefan, H.G. (1999) Stream Temperature-Air Temperature Relationships: A Physical Interpretation. Journal of Hydrology, 218, 128-141. http://dx.doi.org/10.1016/S0022-1694(99)00034-7

[17] Bogan, T., Mohseni, O. and Stefan, H.G. (2003) Stream Temperature-Equilibrium Temperature Relationship. Water Resources Research, 39, 1245. http://dx.doi.org/10.1029/2003WR002034

[18] Bogan, T., Stefan, H.G. and Mohseni, O. (2004) Imprints of Secondary Heat Sources on the Stream TemperatureEquilibrium Temperature Relationship. Water Resources Research, 40, Article ID: W12510. http://dx.doi.org/10.1029/2003WR002733

[19] Larnier, K., Roux, H., Dartus, D. and Croze, O. (2010) Water Temperature Modeling in the Garonne River (France). Knowledge and Management of Aquatic Ecosystems, 398, 20.

[20] Caissie, D., Satish, M.G. and El-Jabi, N. (2007) Predicting Water Temperatures Using a Deterministic Model: Application on Miramichi River Catchments (New Brunswick, Canada). Journal of Hydrology, 336, 303-315. http://dx.doi.org/10.1016/j.jhydrol.2007.01.008

[21] Marcotte, N. and Duong, V.L. (1973) Le calcul de la température de l'eau des rivières. Journal of Hydrology, 18, $273-$ 287. http://dx.doi.org/10.1016/0022-1694(73)90052-8

[22] Younus, M., Hondzo, M. and Engel, B.A. (2000) Stream Temperature Dynamics in Upland Agricultural Watershed. Journal of Environmental Engineering, 126, 518-526. http://dx.doi.org/10.1061/(ASCE)0733-9372(2000)126:6(518)

[23] Hondzo, M. and Stefan, H.G. (1994) Riverbed Heat Conduction Prediction. Water Resources Research, 30, $1503-1513$. http://dx.doi.org/10.1029/93WR03508

[24] Caissie, D. and El-Jabi, N. (1995) Hydrology of the Miramichi River Drainage Basin. In: Chadwick, E.M.P., Ed., Water, Science, and the Public: The Miramichi Ecosystem, Canadian Special Publication of Fisheries and Aquatic Sciences No. 123. NRC Research Press, Ottawa, 83-93.

[25] Cunjak, R.A., Caissie, D. and El-Jabi, N. (1990) The Catamaran Brook Habitat Research Project: Description and General Design of Study. Canadian Technical Report of Fisheries and Aquatic Sciences, No. 1751, 14 p.

[26] Novotny, V. and Krenkel, P.A. (1973) Simplified Mathematical Model of Temperature Changes in Rivers. Journal of the Water Pollution Control Federation, 45, 240-248.

[27] Gu, R. (1998) A Simplified River Temperature Model and Its Application to Streamflow Management. Journal of Hydrology, 37, 35-54.

[28] Marcé, R. and Armengol, J. (2008) Modelling River Water Temperature Using Deterministic, Empirical, and Hybrid Formulations in a Mediterranean Stream. Hydrological Processes, 22, 3418-3430. http://dx.doi.org/10.1002/hyp.6955

[29] Herb, W.R. and Stefan, H.G. (2011) Modified Equilibrium Temperature Models for Cold-Water Streams. Water Resources Research, 47, 13.

[30] Caissie, D., El-Jabi, N. and St-Hilaire, A. (1998) Stochastic Modelling of Water Temperatures in a Small Stream Using Air to Water Relations. Canadian Journal of Civil Engineering, 25, 250-260. http://dx.doi.org/10.1139/197-091

[31] Chenard, J-F. and Caissie, D. (2008) Stream Temperature Modelling Using Artificial Neural Networks: Application on Catamaran Brook, New Brunswick, Canada. Hydrological Processes, 22, 3361-3372. http://dx.doi.org/10.1002/hyp.6928

[32] Beschta, R.L., Bilby, R.E., Brown, G.W., Holtby, L.B. and Hofstra, T.D. (1987) Stream Temperature and Aquatic Habitat: Fisheries and Forestry Interactions. In: Salo, E.O. and Cundy, T.W., Eds., Streamside Management: Forestry and 
Fishery Interactions, University of Washington, Institute of Forest Resources, Seattle, Contribution No. 57, 191-232.

[33] Erickson, T.R. and Stefan, H.G. (2000) Linear Air/Water Temperature Correlations for Streams during Open Water Periods. Journal of Hydrologic Engineering, 5, 317-321. http://dx.doi.org/10.1061/(ASCE)1084-0699(2000)5:3(317)

[34] Stefan, H.G. and Preud'homme, E.B. (1993) Stream Temperature Estimation from Air Temperature. JAWRA Journal of the American Water Resources Association, 29, 27-45. http://dx.doi.org/10.1111/j.1752-1688.1993.tb01502.x 